Artikel Penelitian

\title{
Karakteristik Fisik dan Kimia Tepung Malt Gabah Beras Merah dan Malt Beras Merah dengan Perlakuan Malting pada Lama Germinasi yang Berbeda
}

\section{Physical and Chemical Properties of Rough Red Rice Malt and Red Rice Malt Flour with Malting Treatment in Different Germination Time}

Yasmin Aulia Rachma, Dina Yulia Anggraeni, Lita Lusiana Surja, Siti Susanti, Yoga Pratama*

Program Studi Teknologi Pangan, Fakultas Peternakan dan Pertanian, Universitas Diponegoro, Semarang

*Korespondensi dengan penulis (yogapratama@live.undip.ac.id)

Artikel ini dikirim pada tanggal 4 Juni 2018 dan dinyatakan diterima tanggal 10 Agustus 2018. Artikel ini juga dipublikasi secara online melalui

https://ejournal2.undip.ac.id/index.php/jatp. Hak cipta dilindungi undang-undang. Dilarang diperbanyak untuk tujuan komersial.

Diproduksi oleh Indonesian Food Technologists® @2018

\begin{abstract}
Abstrak
Gabah Beras Merah (GBM) dan Beras Merah (BM) merupakan bahan pangan yang memiliki nilai gizi yang tinggi dan bermanfaat bagi kesehatan. Malting merupakan proses pengolahan serealia dan biji-bijian untuk meningkatkan nilai gizinya dengan tahapan perendaman, germinasi, kemudian pengeringan. Penelitian ini bertujuan untuk mengetahui karakteristik densitas kamba, kelarutan, kadar air, dextrose equivalent, dan aktivitas antioksidan pada tepung malt GBM dan malt BM dengan perlakuan malting pada lama germinasi yang berbeda. Perlakuan malting dilakukan pada lama germinasi $0,24,48$, dan 72 jam. Data dianalisis menggunakan pola regresi. Hasil penelitian menunjukkan bahwa lama germinasi pada proses malting mempengaruhi karakteristik kimia dan fisik tepung malt GBM dan tepung malt BM dengan korelasi sangat kuat. Pembuatan tepung malt BM menghasilkan tepung dengan karakter fisik dan kimia yang lebih baik dibanding GBM. Waktu tahap germinasi proses malting utamanya pada BM masih dapat dioptimalkan sehingga karakteristiknya masih berpotensi untuk ditingkatkan. Kesimpulannya, lama germinasi dapat mempengaruhi karakteristik kimia dan fisik tepung malt, baik untuk GBM maupun BM.
\end{abstract}

Kata kunci : beras merah; gabah; germinasi; malting; tepung.

\begin{abstract}
Rough red rice and red rice have high nutritional value and beneficial to health. Malting is a method of processing cereals and grains to increase its nutritional value by soaking, germination, and drying. This study aims to know the characteristic of bulk density, solubility, moisture content, dextrose equivalent, and antioxidant activity of rough red rice malt flour and red rice malt flour with malting treatment in vaious germination times. The data were analyzed using regression pattern with the treatment of malting germination time $0,24,48$, and 72 hours. Results indicated that the various time of malting germination influenced the chemical and physical properties of rough red rice malt flour and red rice malt flour with very strong correlation. Red rice malt flour had better physical and chemical characteristics than rough red rice malt flour. Germination time in malting process specially for red rice still could be optimized. As conclusion, time of germination affected to the chemical and physical properties of malt flour from rough red rice and red rice.
\end{abstract}

Keywords : red rice; rough red rice; germination; malting; flour.

\section{Pendahuluan}

Beras merah atau BM memiliki berbagai kelebihan dalam kandungan nutrisi dan berpotensi sebagai pilihan bahan pangan fungsional. Dalam BM terkandung pigmen antosianin yang berfungsi sebagai antioksidan, serat, $\gamma$-aminobutiric acid (GABA) yang dapat menekan kadar kolesterol dalam darah, protein, karbohidrat, dan berbagai asam lemak esensial (Pradini et al., 2017). Berbeda dengan BM, gabah beras merah atau GBM yang tidak mengalami proses pengupasan sekam, memiliki kelebihan yaitu masih mengandung protein, vitamin $\mathrm{B}$ kompleks, $\mathrm{E}$ dan $\mathrm{K}$ serta lemak pada bagian sekamnya (Kim et al., 2012).

Untuk meningkatkan nilai gizi dan manfaat BM dan GBM, maka dapat dilakukan suatu proses pengolahan yaitu malting. Proses malting utamanya pada tahap germinasi, enzim hidrolitik teraktivasi untuk kemudian merombak komponen-komponen kompleks pada bahan sehingga menjadi bentuk yang lebih sederhana (Fadilah et al., 2015). Selain itu, proses malting memicu peningkatan nilai gizi bahan dengan memicu terbentuknya berbagai senyawa seperti GABA, asam-asam amino, dan berbagai senyawa fenolik (Maligan et al., 2017). Untuk mempermudah penggunaannya dapat dilakukan dengan penepungan. Namun pemanfaatan GBM sebagai bahan pangan memiliki kelemahan yaitu cenderung menimbulkan rasa pahit, dapat menimbulkan aroma tengik dan warna yang kurang menarik (Astawan dan Febrinda, 2010).

Beberapa penelitian mengenai beras maupun gabah beras yang digerminasi telah dilakukan seperti pada penelitian Kim et al. (2012) mengenai komponen kimia dan fungsional pada gabah beras coklat setelah digerminasi, penelitian Moongngarm dan Saetung 
(2010) mengenai komponen bioaktif dan kimia gabah beras dan beras coklat yang digerminasi, penelitian Maligan et al., (2017) mengenai perbedaan aktivitas antioksidan beras coklat setelah mengalami germinasi dengan lama elisitasi dan germinasi yang berbeda, penelitian Nurhidajah dan Nurrahman (2016) mengenai efek hipoglikemik kecambah beras merah yang diaplikasikan pada tikus, dan beberapa penelitian lainnya. Namun hingga saat ini masih hampir belum ada penelitian mengenai karakteristik tepung dari BM dan GBM setelah dilakukan proses malting.

Penelitian ini dilakukan dengan tujuan untuk mengetahui pengaruh waktu germinasi malting terhadap karakteristik densitas kamba, kelarutan, kadar air, dextrose equivalent, dan aktivitas antioksidan tepung malt BM dan malt GBM. Adapun manfaat dari penelitian ini yaitu untuk memberikan informasi mengenai manfaat proses malting untuk meningkatkan nilai gizi tepung malt GBM dan tepung malt BM dan potensinya sebagai bahan pangan fungsional.

\section{Materi dan Metode \\ Materi}

Bahan yang digunakan dalam penelitian ini antara lain GBM jenis Merah Mawar yang diperoleh dari petani di daerah Kalasan, Kabupaten Sleman Daerah Istimewa Yogyakarta dan BM pecah kulit merk Bionic Farm produksi Kota Bogor.

\section{Metode}

Penelitian dilakukan pada April - Mei 2018 di Laboratorium Rekayasa Pangan dan Hasil Pertanian Fakultas Peternakan dan Pertanian dan Laboratorium Struktur dan Fungsi Tumbuhan Fakultas Sains dan Matematika, Universitas Diponegoro.

Proses malting mencakup perendaman, germinasi, dan pengeringan dilakukan berdasarkan Cheowtirakul et al. (2001) dengan modifikasi. GBM dan BM yang telah dicuci dan disortir ditiriskan kemudian direndam dengan air bersih sebanyak 1:2 selama 2 jam dan ditiriskan kembali. Selanjutnya GBM dan BM yang telah direndam digerminasi dengan cara disebar di nampan plastik dengan ketinggian tumpukan maksimal $0,5 \mathrm{~cm}$ selama 24,48 , dan 72 jam pada suhu ruang dan penyinaran yang cukup. Setiap 6 jam, GBM dan BM disemprot air bersih dan diaduk untuk menjaga kelembaban dan sirkulasi udara yang merata. Terakhir, proses pengeringan dilakukan dengan cara dioven menggunakan oven pengering dengan suhu $50^{\circ} \mathrm{C}$ selama 3 jam.

Penepungan dilakukan sesuai dengan metode yang dilakukan Galung (2017) dengan modifikasi. Malt GBM dan malt BM yang telah dikeringkan dihaluskan hingga menjadi tepung dengan menggunakan grinder (Herb Grinder Maksindo, Indonesia) selama 1 menit kemudian diayak dengan ayakan standar.

\section{Pengujian Morfologi GBM dan BM}

Pengamatan morfologi GBM dan BM setelah digerminasi dilakukan dengan menggunakan digital USB macro cam (LED USB Macro Cam, Cina).

\section{Densitas Kamba}

Uji densitas kamba dilakukan sesuai dengan metode Indriyani et al, (2013) dengan modifikasi. Sampel dimasukkan ke gelas ukur $50 \mathrm{ml}$, kemudian semua sampel dikeluarkan dari gelas ukur dan ditimbang beratnya menggunakan timbangan analitik (Shimadzu, Jepang). Densitas kamba dinyatakan dalam satuan $\mathrm{g} / \mathrm{ml}$ atau $\mathrm{g} / \mathrm{cm}^{3}$.

\section{Uji Kelarutan}

Uji kelarutan dilakukan sesuai dengan metode Lee and Yoo (2011) dengan modifikasi, yaitu dengan cara $0,5 \mathrm{~g}$ sampel dilarutkan dalam $100 \mathrm{ml}$ aquadest. Larutan kemudian dipanaskan selama 30 menit pada suhu $95^{\circ} \mathrm{C}$ pada water bath sambil digoyang goyangkan setiap 5 menit. Pasta didinginkan cepat hingga mencapai suhu ruang kemudian ditimbang 10 gram dalam tube sentrifuge. Suspensi disentrifugasi pada $6000 \mathrm{rpm}$ selama 30 menit dengan menggunakan sentrifuge (Hettich Zentrifugen, Jerman). Supernatant dari sedimen dipisahkan kemudian supernatant dioven pada oven suhu $110^{\circ} \mathrm{C}$ selama 4 jam dan dihitung kelarutannya dengan membagi berat supernatant kering dengan berat suspense pada tabung dikalikan dengan konsentrasi larutannya.

\section{Perhitungan Kadar Air dan Dextrose Equivalent (DE)}

Pengukuran kadar air dilakukan sesuai dengan metode pada Standar Nasional Indonesia (SNI) No. 1971 (2011). Penghitungan DE dengan metode LaneEyenon yang dilakukan oleh Oktafiani dan Tjahjani (2013) dengan modifikasi. Sebelumnya, dilakukan penghitungan Fehling Factor (FF) untuk menentukan konsentrasi larutan glukosa yang akan digunakan dengan mengkalikan kebutuhan titran dengan berat glukosa kemudian dibagi 1000. Nilai DE kemudian dihitung dengan cara $5 \mathrm{~g}$ sampel dilarutkan hingga 100 $\mathrm{ml}$ kemudian dimasukkan ke dalam buret. Dibuat larutan dari $50 \mathrm{ml}$ aquadest, $5 \mathrm{ml}$ larutan fehling $\mathrm{A}, 5 \mathrm{ml}$ larutan fehling $B$, dan $15 \mathrm{ml}$ larutan glukosa yang telah dibuat dengan cara 2,5 g glukosa anhidrat dilarutkan dalam $1000 \mathrm{ml}$ aquadest. Larutan tersebut dididihkan kemudian dititrasi dengan larutan sampel pada buret. Saat dipanaskan, larutan berubah warna menjadi jingga, kemudian setelah dititrasi, larutan akan berubah warna menjadi merah kecoklatan. Nilai DE dihitung berdasarkan hasil titrasi yaitu dengan mengkalikan nilai FF yang telah didapat dengan 100 per konsentrasi sampel dikali kebutuhan titran.

\section{Uji Aktivitas Antioksidan}

Uji aktivitas antioksidan dilakukan sesuai dengan metode yang digunakan Zuhra et al, (2008) dengan modifikasi yaitu dengan metode radikal bebas DPPH (2,2-diphenyl-1 picrylhydrazyl). Sebanyak $10 \mathrm{mg}$ sampel dilarutkan dalam $10 \mathrm{ml}$ metanol (larutan induk 1000 ppm). Larutan tersebut dihomogenkan menggunakan magnetic stirrer (Cimarec, USA) selama 15 menit pada kecepatan 6. Setelah dihomogenkan, larutan tersebut disentrifugasi selama 15 menit pada $5000 \mathrm{rpm}$. Larutan induk tersebut kemudian dibuat konsentrasi 100 ppm, 
200 ppm, 300 ppm, dan 400 ppm. Absorbansi DPPH diukur menggunakan spektrofotometer UV-VIS seri mini 1240 (Shimadzu, Jepang) dengan panjang gelombang $517 \mathrm{~nm}$ setelah didiamkan pada ruang gelap selama 30 menit. Nilai serapan larutan DPPH sebelum dan setelah penambahan sampel dihitung sebagai \% inhibisi. Hasil perhitungan tersebut kemudian dimasukkan ke persamaan regresi dengan konsentrasi ekstrak (ppm) sebagai absis (sumbu $X$ ) dan \% Inhibisi sebagai ordinatnya (sumbu $Y$ ). Nilai $I C_{50}$ didapat dari perhitungan pada saat \% inhibisi sebesar $50 \%$ dengan $Y=a X+b$.

\section{Analisis Data}

Pengujian dilakukan sebanyak 3 kali pengulangan, ditabulasi dengan menggunakan Microsoft Excel 2013. Pada hasil percobaan parameter kadar air digunakan pola regresi polinomial, dan pada hasil percobaan densitas kamba, kelarutan, DE, dan aktivitas antioksidan digunakan pola regresi linier.

\section{Hasil dan Pembahasan}

\section{Morfologi GBM dan BM Setelah Germinas}

Figur 1A menunjukkan bahwa GBM setelah proses germinasi selama 24 jam belum menunjukkan banyak perubahan, namun sudah terlihat adanya pemecahan pada bagian perikarp gabah. Setelah proses germinasi malting selama 48 jam, sudah tampak adanya radikula yang menyembul dengan panjang sekitar 1 hingga $3 \mathrm{~mm}$. Sedangkan, germinasi GBM dengan lama malting 72 jam menunjukkan radikula tumbuh dengan pesat hingga sekitar 1 sampai 1,5 cm, dan sudah muncul plumula atau fase pertumbuhan embrio yang akan menjadi bakal batang. Figur 1B menunjukkan BM yang telah mengalami germinasi selama 24 jam sudah tampak munculnya radikula sekitar $0,5 \mathrm{~mm}$. Setelah germinasi 48 jam panjang radikula menjadi 1 hingga 2 $\mathrm{mm}$, dan pada 72 jam radikula semakin memanjang hingga sekitar 2 hingga $3 \mathrm{~mm}$, dan plumula mulai tumbuh pada jam ke 48 dan semakin terlihat pada jam ke 72 . Hasil tersebut sesuai dengan Ekowati dan Purwestri (2016) yang menyatakan bahwa germinasi beras selama 24 jam menghasilkan radikula dengan panjang 0,5 sampai $1 \mathrm{~mm}$ dan dapat terus memanjang. Hasil ini juga sesuai dengan Ballo et al. (2012) bahwa padi dapat dikatakan tergerminasi ketika radikula telah pencapai panjang $\pm 2 \mathrm{~mm}$.

Seperti yang dapat dilihat pada Figur 1, germinasi dapat dilakukan pada GBM maupun BM. Meskipun telah mengalami penyosohan, namun pada BM masih dapat terjadi perkecambahan karena masih adanya lapisan aleuron dimana enzim a-amilase sebagai enzim yang berperan dalam germinasi tersintesis (Campbell et al., 2012). Meski begitu, pertumbuhan radikula pada GBM lebih cepat terjadi dibandingkan pada BM. Hal tersebut dapat terjadi karena proses penyosohan pada BM telah menghilangkan beberapa lapisan gabah seperti pericarp dan tegmen yang juga mengandung enzim-enzim hidrolitik yang berperan dalam proses germinasi, sehingga pada GBM pertumbuhan radikula lebih efektif (Astawan dan Febrinda, 2010). Akan tetapi, hal ini juga mengindikasikan bahwa proses malting selama 72 jam belum optimal pada BM sehingga memungkinkan penambahan waktu malting yang yang lebih panjang.
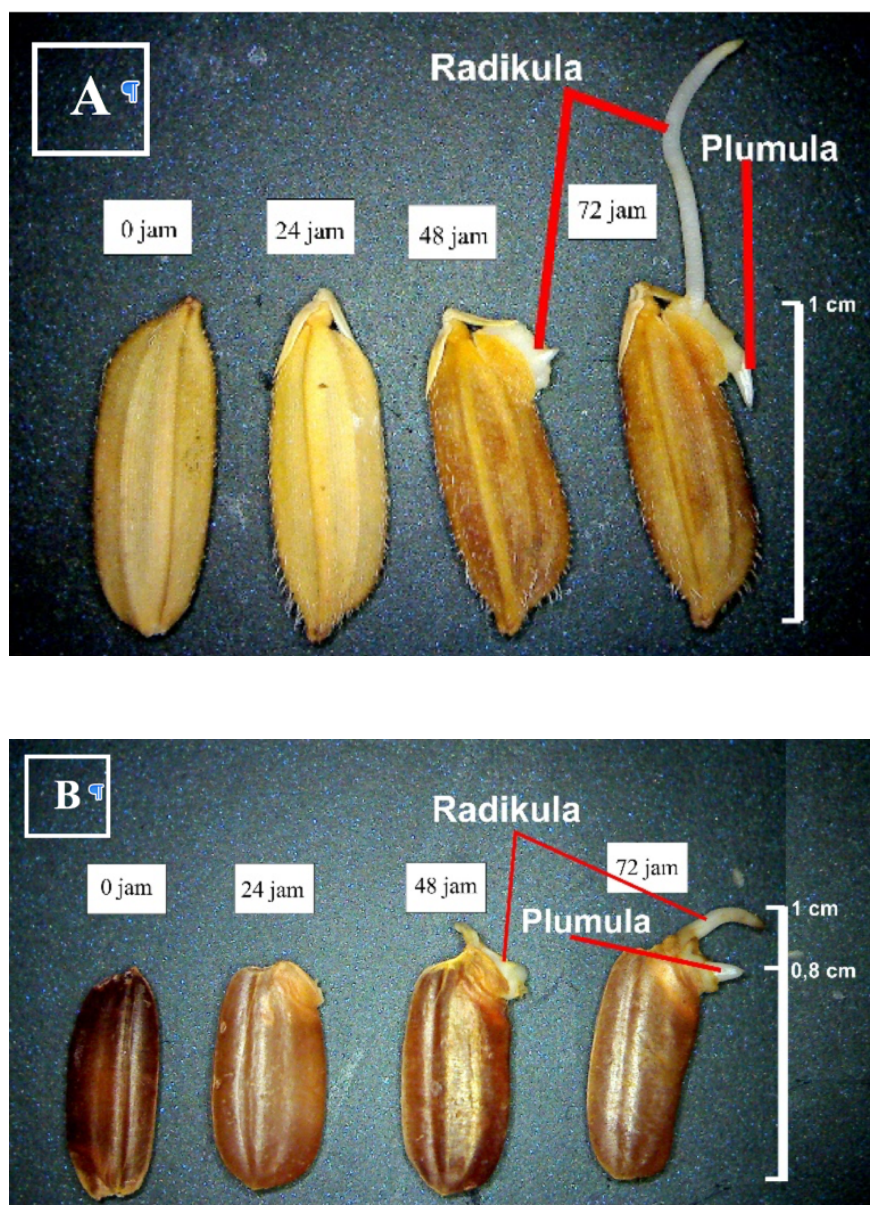

Figur 1. Morfologi GBM (A) dan BM (B) dengan Perlakuan Malting pada Lama Germinasi 0, 24, 48, dan 72 Jam.

\section{Densitas Kamba}

Densitas kamba tepung malt GBM (Figur 2A) cenderung mengalami peningkatan seiring lama waktu germinasi proses malting dengan gradien sebesar 0,0007, $R^{2}$ 98,87\% dan korelasi 99,43\% (sangat kuat). Sedangkan pada tepung malt BM (Figur 2B) cenderung mengalami penurunan dengan gradien 0,001 pada $R^{2}$ $97,21 \%$ dan korelasi yang sangat kuat.

Peningkatan nilai densitas kamba pada tepung malt GBM dan penurunan nilai densitas kamba tepung malt BM tersebut berkaitan dengan kadar air tepung (Figur 4). Kadar air yang tinggi mengisi ruang antar partikel dan mengakibatkan partikel tepung malt GBM akan cenderung semakin melekat sehingga volume tepung menurun dan tepung malt GBM semakin tidak kamba. Sebaliknya, kadar air pada tepung malt BM mengalami penurunan sehingga berat tepung mengalami penurunan pula dan volume meningkat karena air yang menempati cela antar partikel berkurang. Cucikodana et al. (2012) dan Ardhianditto et al. (2013) bahwa kecenderungan kadar air bahan berbanding terbalik dengan kekambaan bahan, semakin tinggi kadar air bahan, mengakibatkan nilai densitas kambanya naik dan kekambaan bahan tersebut menurun. 

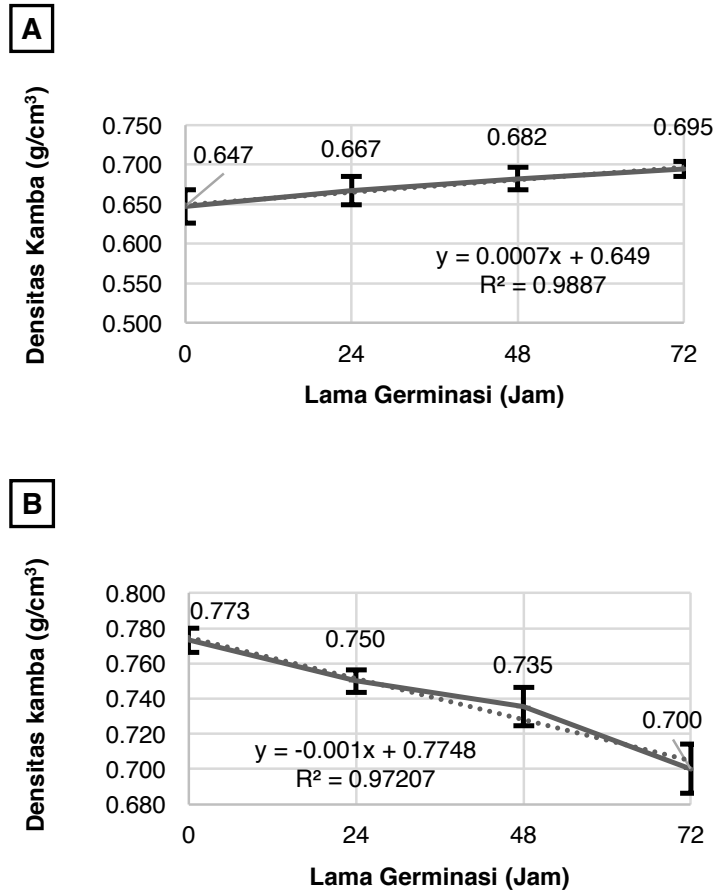

Figur 1. Grafik Densitas Kamba Tepung Malt GBM (A) dan Tepung Malt BM (B) dengan Perlakuan Malting pada Lama Germinasi 0, 24, 48, dan 72 jam.

Besarnya densitas kamba tepung malt GBM tersebut lebih kecil dibandingkan dengan densitas kamba tepung BM (Indriyani et al., 2013) yaitu sebesar 0,697, namun masih sesuai dengan densitas kamba pangan bubuk pada umumnya yaitu 0,3-0,8 $\mathrm{g} / \mathrm{cm}^{3}$ (Ardhianditto et al., 2013). Selain kadar air, densitas kamba tepung juga dapat dipengaruhi oleh beberapa faktor, diantaranya ukuran partikel, dan poroitas tepung (Purwitasari et al., 2014). Semakin porous tepung, densitas kamba akan menurun dan tepung semakin kamba (Atmaka dan Sigit, 2010).

\section{Kelarutan}

Berdasarkan Figur 3 dapat dilihat bahwa lama germinasi malting mempengaruhi nilai kelarutan tepung malt GBM dan tepung malt BM. Kelarutan tepung malt GBM cenderung mengalami kenalikan dengan $R^{2}$ sebesar $98,76 \%$ dan memiliki korelasi sangat kuat $(R=$ 99,38), sedangkan pada tepung malt BM cenderung mengalami kenaikan kelarutan dengan $R^{2}$ sebesar $94,98 \%$ dan korelasi sangat kuat $(R=97,46 \%)$.

Berdasarkan data Figur 3, diketahui pada kedua jenis tepung terjadi kenaikan nilai kelarutan dengan taraf kenaikan pada tepung malt GBM sebesar 0,1957, sedangkan pada tepung malt BM sebesar 0,2182. Hal tersebut menunjukkan bahwa kenaikan nilai kelarutan pada tepung malt BM lebih tinggi dibanding pada tepung malt GBM. Naiknya nilai kelarutan tepung malt GBM dan tepung malt BM dapat terjadi akibat semakin banyaknya kandungan komponen larut air pada tepung akibat adanya pemecahan molekul kompleks menjadi sederhana selama proses germinasi malting. Pangastuti et al. (2013) menyatakan tinggi rendahnya kelarutan disebabkan oleh kandungan komponen-komponen larut air dan tidak larut air dalam bahan. Pada proses germinasi malting, enzim-enzim hidrolitik yang teraktivasi merombak berbagai komponen kompleks pada GBM menjadi komponen sederhana. Enzim amilase mengkatalis perombakan karbohidrat pati dan menghasilkan gula dengan komponen yang lebih sederhana (Fadilah et al., 2015). Enzim lipase menghidrolisis lemak pada GBM menjadi asam lemak dan gliserol, serta enzim protease yang dapat memecah ikatan-ikatan peptida protein dan menghasilkan asam amino (Gardner et al., 2008). Hasil-hasil perombakan tersebut bersifat larut air, sehingga semakin lama proses germinasi malting, semakin banyak komponen yang terombak menjadi lebih sederhana dan meningkatkan kelarutan tepung (Pangastuti et al., 2013). Sehingga dapat dikatakan bahwa proses perombakan komponen pada germinasi BM lebih optimal dibandingkan pada GBM dilihat dari taraf kenaikan nilai kelarutan tepung malt BM yang lebih tinggi dibanding tepung malt GBM.
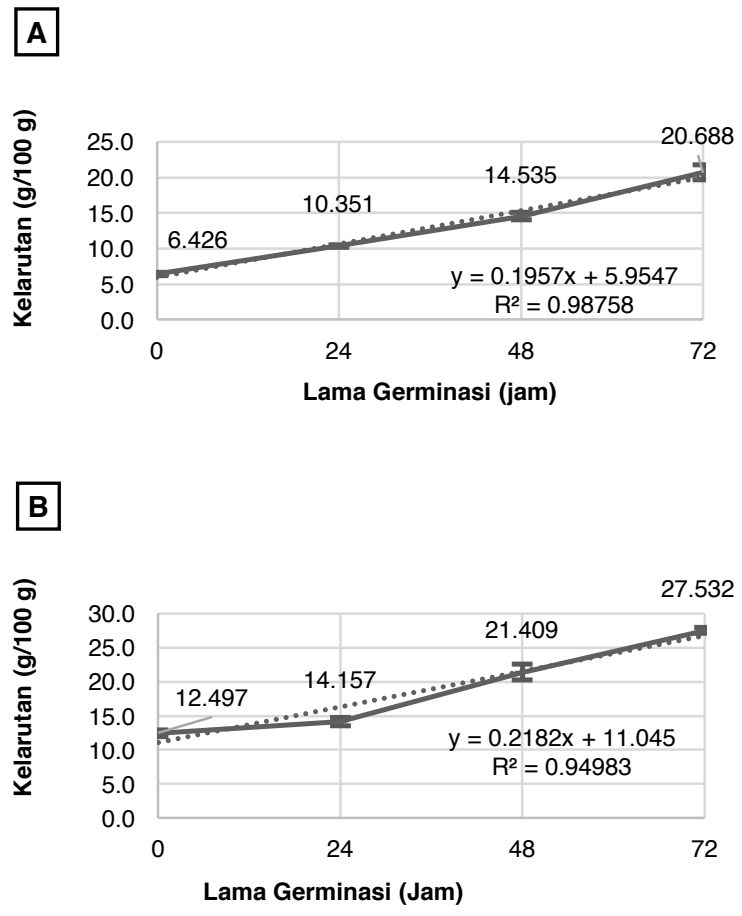

Figur 2. Figur Grafik Kelarutan Tepung Malt GBM (A) dan Tepung Malt BM (B) dengan Perlakuan Malting pada Lama Germinasi 0, 24, 48, dan 72 jam.

\section{Kadar Air}

Figur 4 menunjukkan grafik kadar air pada tepung malt GBM dan tepung malt BM menggunakan pola regresi polinomial kuadrat 2 berbentuk parabola. Pada grafik kadar air tepung malt GBM, Nilai a bernilai negatif, sehingga grafik parabola membuka ke bawah dengan satu titik puncak maksimum dengan koefisien determinasi $\left(R^{2}\right) \quad 96,46 \%$ dan korelasi sangat kuat $(R=98,21 \%)$. Diketahui bahwa kadar air tepung malt GBM cenderung mengalami peningkatan hingga titik puncak kemudian cenderung mengalami penurunan seiring lama waktu germinasi malting. Pada tepung malt BM, grafik membuka ke atas dengan satu titik puncak minimum dengan $R^{2} 97,16 \%$ dan korelasi sangat kuat $(R=98,57 \%)$. Sehingga diketahui tren kadar air tepung malt BM cenderung menurun hingga titik puncak 
minimum kemudian cenderung mengalami peningkatan seiring lama waktu germinasi malting. Hasil dapat diprediksi berdasarkan persamaan yang didapat.

A

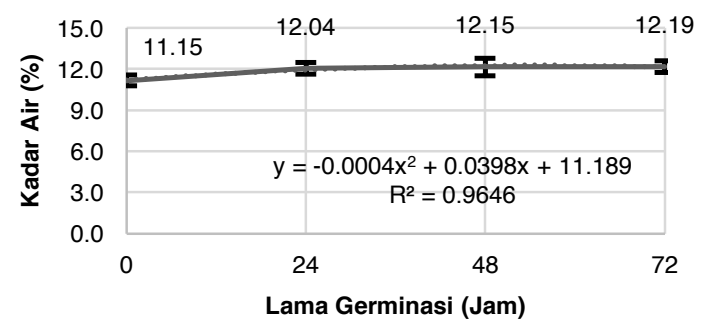

B

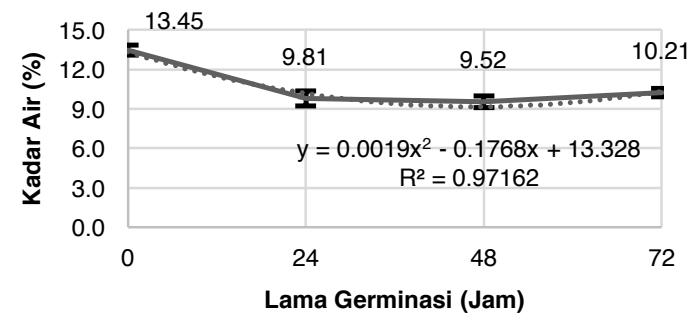

Figur 3. Grafik Kadar Air Tepung Malt GBM (A) dan Tepung Malt BM (B) dengan Perlakuan Malting pada Lama Germinasi $0,24,48$, dan 72 Jam

Nilai gradien perubahan kadar air tepung malt GBM $(0,0004)$ lebih kecil dibandingkan gradien tepung malt BM $(0,0019)$. Gradien tersebut menunjukkan bahwa perubahan nilai kadar air tepung malt BM lebih pesat dibanding tepung malt GBM. Hal tersebut terjadi karena adanya perbedaan komponen GBM dan BM sebagai bahan baku. Pada GBM masih terdapat husk (sekam padi) dan lapisan bran yang merupakan lapisan kulit beras dan berfungsi dalam melindungi bagian dalam beras, sedangkan pada BM sudah tidak ada.

Thakur and Gupta. (2014) menyatakan lapisan husk pada beras utuh berfungsi sebagai barrier untuk melindungi bagian dalam beras dan menghambat absorbsi air karena kandungan crude lipid nya. Pada proses perendaman dan selama proses germinasi, air masuk sedikit demi sedikit ke dalam GBM hingga mencapai puncak kadar air maksimum yang terserap karena adanya barrier tersebut, sedangkan pada BM air langsung banyak yang terserap selama proses perendaman, sehingga kandungan air BM pada proses perendaman telah mencapai titik maksimum dan tidak mengalami penyerapan kembali hingga air yang terserap berkurang karena digunakan selama proses germinasi dan adanya penguapan. Hal tersebut sesuai dengan Bello et al. (2007) bahwa absorbsi air dalam beras akan meningkat selama proses perendaman kemudian berhenti pada kapasitas maksimum absorbsi. Thahir (2010) menyatakan lapisan terluar gabah berifat impermeable dan menghambat difusi $\mathrm{O}_{2}, \mathrm{CO}_{2}$, dan air, penyosohan mengakibatkan hilangnya pelindung ini sehingga difusi dapat lebih mudah terjadi.
Kadar air tepung malt GBM lebih tinggi dibandingkan kadar air tepung BM pada penelitian Indriyani et al., (2013) yaitu 9,850 hingga 10,557\%, sedangkan kadar air tepung malt BM mendekati. Kadar air kedua jenis tepung, kecuali pada tepung malt BM kontrol (tanpa germinasi) sesuai dengan standar SNI No. 3549 tahun 2009 yaitu maksimal sebesar 13\% (SNI, 2009).

\section{Dextrose Equivalent (DE)}

Figur 5 menunjukkan pada tepung malt GBM cenderung mengalami kenaikan pada gradien 0,0033 dengan $\mathrm{R}^{2}$ sebesar $98,77 \%$ dan korelasi yang sangat kuat $(R=99,38 \%)$ antara lama germinasi dengan nilai $\mathrm{DE}$. Sedangkan tepung malt $\mathrm{BM}$ cenderung mengalami kenaikan dengan gradien sebesar 0,0102 dengan nilai $R^{2}$ sebesar $91,75 \%$ dan korelasi antara lama germinasi dan nilai $D E$ yang sangat kuat $(R=95,79 \%)$.
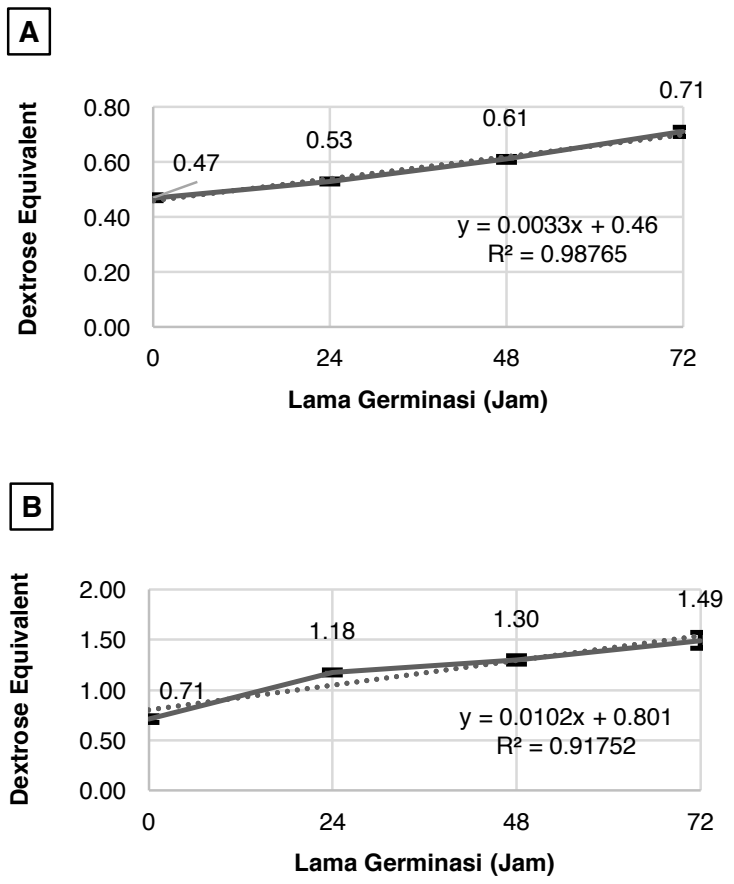

Figur 4. Dextrose Equivalent Tepung Malt GBM (A) dan Tepung Malt BM (B) dengan Perlakuan Malting pada Lama Germinasi selama 0, 24, 48, dan 72 Jam.

Berdarkan pada Figur 5, terjadi peningkatan nilai DE dengan taraf kenaikan yang berbeda pada kedua jenis tepung. Tepung malt BM mengalami peningkatan nilai $D E$ yang lebih tinggi dibanding tepung malt GBM dilihat dari nilai gradien nya. Itu menunjukkan bahwa proses malting pada BM lebih efektif dalam peningkatan nilai DE dibanding BM. Kenaikan nilai DE kedua jenis tepung ini diakibatkan oleh semakin banyaknya ikatan rantai karbohidrat (pati) GBM maupun BM yang terhidrolisis menjadi lebih sederhana dan pada ujung rantainya mengandung gugus aldehid atau keton bebas. Hal tersebut sesuai dengan Santosa (2010) bahwa semakin lama waktu hidrolisis, nilai DE produk akan semakin tinggi karena pati yang terkonversi dengan bantuan katalis enzim dan membentuk gula sederhana semakin banyak. Dalam tahap germinasi proses malting, 
air yang terserap memutus ikatan 1-4a glukosida menjadi lebih pendek dikatalis oleh enzim a-amilase dengan (Yuniwati et al., 2011).
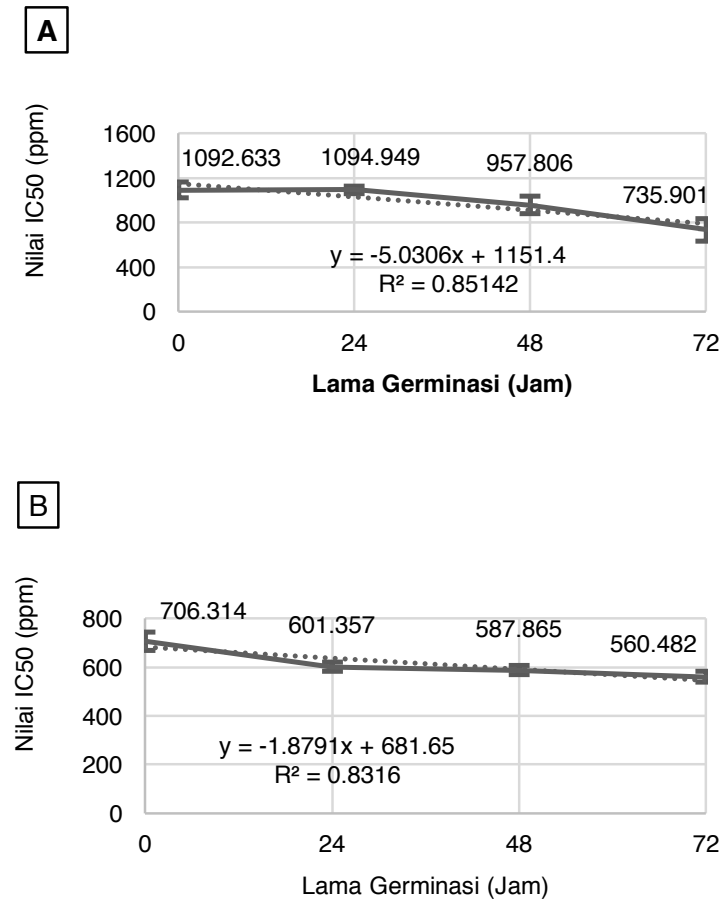

Figur 5. Grafik Nilai $I_{50}$ Tepung Malt GBM (A) dan Tepung Malt BM (B) dengan Perlakuan Malting pada Lama Germinasi $0,24,48$, dan 72 Jam.

\section{Aktivitas Antioksidan}

Figur 6 menunjukkan terjadinya penurunan nilai $\mathrm{IC}_{50}$ pada kedua jenis tepung seiring lama germinasi malting. Terjadi penurunan dengan gradien 5,0306 pada koefisien determinasi sebesar $85,14 \%$ dan korelasi yang sangat kuat $(R=92,27 \%)$ pada tepung malt GBM. Sedangkan pada tepung malt $\mathrm{BM}$ penurunan nilai $\mathrm{IC}_{50}$ terjadi dengan gradient sebesar 1,8791 pada koefisien determinasi $83,16 \%$ dan korelasi yang sangat kuat $(R=$ $91,19 \%)$.

Penurunan nilai $\mathrm{IC}_{50}$ tersebut dapat menunjukkan semakin tingginya aktivitas antioksidan kedua jenis tepung tersebut seiring lamanya waktu germinasi malting. Phattayakom et al. (2016) menyatakan dalam penelitiannya bahwa pada proses germinasi beras, terjadi peningkatan komponen bioaktif seperti $Y$ aminobutyric acid (GABA) dan kandungan senyawa fenolik serta aktivitas antioksidan, salah satunya adalah karena adanya sintesis enzim hidrolitik yang memicu berbagai perubahan komponen beras. Hal tersebut didukung oleh pernyataan Maligan et al. (2017) yang menyatakan bahwa selama proses germinasi berbagai kultivar beras terjadi peningkatan aktivitas antioksidan karena terjadinya aktivasi enzim hidrolitik, polisakarida non pati, dan protein sehingga mengakibatkan peningkatan beberapa komponen gizi dan menghasilkan senyawa antioksidan baru seperti $Y$-oryzanol, $Y$ aminobutyric acid (GABA), berbagai senyawa fenolik dan asam amino yang dapat meningkatkan aktivitas antioksidan pada bahan.
Nilai gradien pada kedua jenis tepung menunjukkan bahwa peningkatan nilai aktivitas antioksidan pada tepung malt GBM lebih besar dibandingkan pada tepung malt BM (Figur 6). Hal tersebut berkaitan dengan kemampuan pembentukan senyawa fenolik baru selama proses germinasi. Walter dan Marchesan (2011) menyatakan bahwa peningkatan aktivitas antioksidan berkaitan dengan kemampuan atau kekuatan pembentukan senyawa fenolik baru yang berperan dalam peningkatan aktivitas antioksidan. Didukung oleh pendapat Pertiwi et al. (2013) bahwa peningkatan aktivitas antioksidan dipengaruhi oleh pembentukan senyawa-senyawa fenolik selama proses germinasi. Dilihat dari morfologinya (Figur 1), lebih kecilnya peningkatan aktivitas antioksidan pada tepung malt BM berhubungan dengan belum optimalnya tahap germinasi pada proses malting pada BM, sehingga pembentukan senyawa fenolik baru belum maksimal.

\section{Kesimpulan}

Berdasarkan penelitian, lama germinasi malting mempengaruhi kadar air, densitas kamba, kelarutan, nilai Dextrose Equivalent, dan aktivitas antioksidan tepung malt GBM dan tepung malt BM dengan korelasi yang sangat kuat. Malting pada BM menghasilkan tepung malt dengan karakteristik yang lebih baik dibandingkan dengan GBM khususnya dari sisi kelarutan, dan nilai DE-nya. Di sisi lain, malting pada BM masih belum mencapai titik optimal yang terlihat dari perkembangan morfologi plumula dan radikula. Oleh karenanya proses malting pada BM masih dapat dioptimalkan untuk menghasilkan karakteristik produk yang lebih baik lagi.

\section{Ucapan Terimakasih}

Penulis mengucapkan terimakasih kepada Direktorat Pembelajaran dan Kemahasiswaan Kementrian Ristekdikti yang telah mebiayai penelitian ini melalui Program Kreativitas Mahasiswa (PKM) bidang Penelitian Eksakta pada tahun pendanaan 2018.

\section{Daftar Pustaka}

Ardhianditto, D., Affandi, D.R., Riyadi, N.H., Anandito, R.B.K. 2013. Kajian karakteristik bubur bayi instan berbahan dasar tepung millet kuning (Panicum sp) dan tepung beras merah (Oryza nivara) dengan flavor alami pisang ambon (Musa $X$ paradisiaca $L$ ) sebagai makanan pendamping asi (MP-ASI). Jurnal Teknosains Pangan. 2(1):88-96.

Astawan, M., Febrinda, A.E. 2016. Potensi dedak dan bekatul beras sebagai ingredient pangan dan produk pangan fungsional. Jurnal Pangan 19 (1):14-21.

Atmaka, W., Amanto, B.S. 2010. Kajian karakterikstik fisikokimia tepung instan beberapa varietas jagung (Zea mays L.). Jurnal Teknologi Hasil Pertanian 3(1):13-20.

Bello, M.O., Tolaba, M.P., Suarez, C. 2007. Water absorption and starch gelatinization in whole rice grain during soaking. Jurnal LWT-Food science 
and Technology 40(2):313-318. DOI:10.1016/ j.Iwt.2005.09.017

Campbell, N.A., Reece, J.B., Mitchell, L.G. 2012. Biologi. Edisi Kedelapan, Jilid 5. Erlangga, Jakarta.

Cheowtirakul, C., Chaijanya, P., Jirathumkitkul, P., Kriangkraiphiphat, K., Ampunsang, M., Ruangchai, D. 2001. A study on rice milk production. Assumption University Journal of Technology 4(3):143-156. DOI: 10.1016/ j.foodchem.2010.05.115

Ekowati, N.Y., Purwestri, Y.A. 2016. Analisis kandungan gamma aminobutyric acid (GABA), fenol total dan aktivitas antioksidan "beras kecambah" kultivar lokal (Oryza sativa L.) di Yogyakarta. Jurnal Agricola 6(2):117-127.

Fadilah, Rochmadi, Syamsiah, S., Haryadi. 2015. Hydrolysis of starch in porang flour using alpha amylase. Journal of Engineering Science and Technology 6(1):1-8.

Indri, F.S. 2017. Karakterisasi dan pengaruh berbagai perlakuan terhadap produksi tepung beras merah (Oryza nivara) instan. Jurnal Pertanian Berkelanjutan 5(2):37-42.

Gardner, F.P., Pearce, R.B., Mitchell, R.L. 2008. Fisiologi Tanaman Budidaya. UI Press, Jakarta.

Indriyani, F., Nurhidajah., Suyanto, A. 2014. Karakteristik fisik, kimia dan sifat organoleptik tepung beras merah berdasarkan variasi lama pengeringan. Jurnal Pangan dan Gizi 4(2):27-34.

Kim, H.Y., Hwang, I.G., Kim, T.M., Woo, K.S., Park, D.S., Kim, H.J., Kim, D.J., Lee, J., Jeong, H.S. 2012. Chemical and functional components in different parts of rough rice (Oryza sativa L.) before and after germination. Jurnal Food Chemistry 134(1):288-293. DOI:10.1016/ j.foodchem.2012.02.138

Lee, H.L., Yoo, B. 2011. Effect of hydroxypropylation on physical and rheological properties of sweet potato starch. J. LWT-Food Science and Technology 44(3), pp.765-770. DOI:10.1016/ j.Iwt.2010.09.012

Maligan, J.M., Lestary, M., Wani, Y.A. 2017. Perbedaan aktivitas antioksidan kecambah beras coklat (Oryza Sativa L.) berdasarkan lama proses elisitasi dan waktu perkecambahan. Indonesian Journal of Human Nutrition 4(2):108-116.

Moongngarm, A., Saetung, N. 2010. Comparison of chemical compositions and bioactive compounds of germinated rough rice and brown rice. Journal Food Chemistry 122(3):782-788. DOI:10.1016/ j.foodchem.2010.03.053
Nurhidajah, N., Nurrahman, N. 2017. Efek hipoglikemik kecambah beras merah pada tikus yang diinduksi STZ-NA dengan parameter kadar insulin, indeks HOMA-IR dan HOMA $\beta$. Jurnal Agritech 36(4):433-439.

Oktafiani, N. I. E., Tjahjani, S. 2013. Karakterisasi hasil dan penentuan laju reaksi sakarifikasi dekstrin umbi suweg (Amorphophalus campanulatus BI) menjadi sirup glukosa. UNESA Journal of Chemistry 2(3): 167-174.

Pangastuti, H.A., Affandi, D.R., Ishartani, D. 2013. Karakterisasi sifat fisik dan kimia tepung kacang merah (Phaseolus vulgaris L.) dengan beberapa perlakuan pendahuluan. Jurnal Teknosains Pangan. 2(1):20-29.

Pradini, W.U., Marchianti, A.C.N., Riyanti, R. 2017. The effectivenes of red rice to decrease total cholesterol in type $2 \mathrm{dm}$ patients. Journal of Agromedicine and Medical Sciences 3(1):7-12.

Purwitasari, A., Hendrawan, Y., Yualianingsih, R. 2014. Pengaruh suhu dan waktu ekstraksi terhadap sifat fisik kimia dalam pembuatan konsentrat protein kacang komak (Lablab purpureus (L.) sweet). Jurnal Bioproses Komoditas Tropis 2(1):42-53.

Santosa, H. 2010. Hidrolisa enzimatik pati tapioka dengan kombinasi pemanas microwave-water bath pada pembuatan dekstrin. Jurnal Momentum. 6(2):29-35

SNI (Standar Nasional Indonesia) 1971-2011 Cara Uji Kadar Air Agregat dengan Pengeringan. 2011. Badan Standardisasi Nasional. Jakarta.

SNI (Standar Nasional Indonesia) 3549-2009 Tepung Beras. 2009. Badan Standardisasi Nasional. Jakarta.

Thahir, R. 2010. Revitalisasi penggilingan padi melalui inovasi penyosohan mendukung swasembada beras dan persaingan global. Jurnal Pengembangan Inovasi Pertanian 3(3):171-183.

Thakur, A.K., Gupta, A.K. 2006. Water absorption characteristics of paddy, brown rice and husk during soaking. Journal of Food Engineering 75(2):252-257. DOI:10.1016/j.jfoodeng.2005.04. 014

Walter, M., Marchesan, E. 2011. Phenolic compounds and antioxidant activity of rice. Brazilian Archives of Biology and Technology 54(2), pp.371-377. DOI: 10.1590/S1516-89132011000200020

Yuniwati, M., Ismiyati, D., Kurniasih, R. 2011. Kinetika reaksi hidrolisis pati pisang tanduk dengan katalisator asam chlorida. Jurnal Teknologi 4(2):107-112.

Zuhra, C.F., Tarigan, J.B., Sihotang, H. 2008. Aktivitas antioksidan senyawa flavonoid dari daun katuk (Sauropus androgunus (L) Merr.). Jurnal Biologi Sumatera 3(1):7-10. 